\title{
Assessment of Knowledge of Saudi Mothers Regarding Causes of Obesity Among Children, Riyadh, Saudi Arabia
}

\author{
Budur Al Harthi ${ }^{1} \quad$ Maha El-Araby ${ }^{2}$ \\ 1.School of nursing, king Saud university, kingdom of Saudi Arabia \\ 2.College of Nursing .Tanta University .Egypt
}

\begin{abstract}
During the last few decades, the Kingdom of Saudi Arabia (KSA) experienced rapid socio-cultural changes caused by the accelerating economy in the Arabian Gulf region. That was associated with major changes in the activities, food choices and eating habits which, progressively, became more and more "Westernized". Such "a nutritional transition" has been claimed for the rising rates of overweight and obesity which were recently observed among Saudi children. Therefore the objective of this study is to assess the knowledge of Saudi mothers regarding causes of obesity among children Descriptive cross sectional design was utilized in this study. The study was carried out from mothers at work, and from a community at shopping malls, and the beauty salons., Riyadh city, (KSA). The study population included a convenient sample of 254 mothers was interviewed in a semi structured interview. Data were collected from October to December, 2015. The tool used was an interview questionnaire which developed and used to collect the necessary data, the questionnaire consisted of 3 parts that include demographics, Questions related to children's lifestyle and questions related to mother's knowledge of causes of obesity among children. The results showed that more than half of the sample was in age group 31 to 40 years old about a quarter had high school education, the majority of the sample was married and nearly about two third of them were working. Regarding lifestyle of children, data showed that more than three quarters of children in this study did not practice any kind of sport, while one eights of them practice sport for 3 to 4 hours per day. More than half of the children receive 3 basic meals a day, while nearly two third of them eat fast food sometimes., the majority of mothers know that unbalanced diet could be a cause of obesity among children, while about one third of them don't know that family problems might be a reason for obesity among children. Some demographic variables such as age, education, work, and income were correlated to total mother's knowledge of causes of obesity among children. The study concluded that thechildren in this study had poor life style regarding practicing of sport, fast food, preferred food elements, watching TV, video games and diet regimen. Mother's knowledge about causes of obesity among children conveyed a relatively good level. It is recommended strategies and coordinated efforts at all levels to reduce the tendency of overweight, obesity and elevated body fat, and to promote healthy life style in our youth.
\end{abstract}

Keywords: knowledge, causes of obesity, children

DOI: $10.7176 / \mathrm{JHMN} / 61-03$

Publication date: April $30^{\text {th }} 2019$

\section{Introduction}

Obesity is not the same as overweight, which means a child's weight is in the upper range of children of the same age and height. Overweight may be due to extra muscle, bone, or water, as well as too much fat. Both terms mean that a child's weight is higher than what is thought to be healthy. Obesity, a state of excess body fat, is commonly assessed using the body mass index (BMI), a ratio of weight $(\mathrm{kg})$ height $\left(\mathrm{m}^{2}\right)$, and a BMI of over $30 \mathrm{~kg} / \mathrm{m}^{2}$ is considered obese.(U.S. National Library of Medicine, 2015)In children, the BMI is plotted on growth charts for interpretation relative to a healthy reference population and percentiles are then used to define obese ( $>95$ th percentile) and overweight ( $>85$ percentile). The prevalence of obesity and overweight among children has shown dramatic increases over the past 25 years(Statistics Canada, "Body mass index (BMI) for children and youth 2007 to 2009.)

Children are surrounded by many things that make it easy to overeat and harder to be active. Foods that are high in fat and sugar content often come in large portion sizes. These factors can lead children to take in more calories than they need before they feel full. TV commercials and other screen ads can lead to unhealthy food choices. Most of the time, the food in ads aimed at kids is high in sugar, salt, or fats.(U.S. Preventive Services Task Force. 2010.)

Other factors in the child's environment can also lead to obesity. Family, friends, and school setting help shape a child's diet and exercise choices. Food may be used as a reward or to comfort a child. These learned habits can lead to overeating. Many people have a hard time breaking these habits later in life.(Gahagan S.2011)Genetics, medical conditions, and emotional disorders can also increase a child's risk for obesity. Hormone disorders or low thyroid function, and certain medications, such as steroids or anti-seizure medications, can increase a child's appetite. Over time, this increases their risk for obesity. A child who is overweight or obese is more likely to be overweight or obese as an adult. Obese children are now developing health problems that used to be seen only in 
adults. When these problems begin in childhood, they often become more severe when the child becomes an adult.(Seagle HM... etal 2009)

\section{Materials and Methods}

\subsection{Magnitude of the problem:}

In Saudi Arabia, obesity has become one of the most common health problems affecting children of both sexes and all age groups. Prevalence of overweight and obesity among children and adolescent 5-18 years was $23.1 \%$, $11.3 \%$ respectively. Prevalence of overweight and obesity among females of childbearing age were $31.5 \%$ and $21 \%$ respectively.(Al-Othaimeen AI, et al 2007) (AL-Nozha MM, et al 2005)

\subsection{Aim of the study}

This study aims to assess the knowledge of Saudi mothers regarding causes of obesity among children.

\subsection{Research Design}

Descriptive cross sectional design was utilized in this study.

\subsection{Sample}

A convenient sample of 254 mothers was interviewed in a semi structured interview.

\subsection{Setting}

Data were collected from mothers at work, and from a community at shopping malls, and the beauty salons.

\subsection{Tools}

The questionnaire in this study was developed by the researchers after reviewing related literatures and studies that share goals of the present study. The questionnaire consisted of 3 parts that include demographics such as mother's age, marital status, education, work, income, number of kids, and having an obese child. Questions related to children's lifestyle such as practicing sports, type of sport, time spent in practicing sport, meal time, preferred food elements, eating breakfast, eating fast food, watching TV, using internet, and playing video games. In addition, the questionnaire included 14 questions related to mother's knowledge of causes of obesity among children. Responses to the knowledge questions were know and don't know. Validity of the questionnaire was tested by being reviewed by a panel of $3 \mathrm{PhD}$ holders specialized in pediatric nursing and research methodology. Reliability of the questionnaire was tested before the main analysis of the results and reported a Cronbach's alpha of .85 .

\section{Pilot Study}

A pilot study was conducted on 10 Saudi women, to test feasibility of tools and time required to be applied. Simple modification was done by omission of some items of the interview questionnaire that they were not consistent with this study.

\section{Administrative design}

Before the conduction of the pilot study as well as the actual study, an official permission was obtained from the responsible person in each setting.

\section{Procedure: or (Protection of human subjects)}

The researchers approached mothers and explained about the study objectives. Participants were told that participation is voluntary and they have the right to withdraw at any time. Mothers who have kids and willing to participate in the study were asked to sign consent. The interview lasted from 15 to 20 minutes and the researchers were available to answer questions

\section{Statistical Analysis}

Collected data were coded and analyzed. Descriptive statistics for the variables were calculated. Variables were compared using frequency distribution. The variables were significant at $\mathrm{P}$ value less than 0.05 . All the analysis was performed using SPSS package version 20.

\section{Results}

Demographic characteristics of the sample:

Descriptive statistic of the study variables showed that $61.9 \%$ of the sample was in age group 31 to 40 years old, and $20.6 \%$ was in the age group 20 to 30 years old. $47.6 \%$ of the sample was university graduates and about a quarter had high school education. $90 \%$ were married, $55.5 \%$ were working, and the rest were house wives. $88 \%$ have a fixed family income; $34.4 \%$ of them earn more than 10,000 Saudi Riyals per month. On the other hand, $28 \%$ have a monthly income of 7 to 10,000 Saudi riyals per month and $27.2 \%$ have a monthly income of 3 to 7,000 SR. $41 \%$ of the sample live in a family that consists of 5 to 7 members, $29 \%$ live in a family of 1 to 4 members and $23 \%$ live in a big family of 8 to 10 members. $13 \%$ of the mothers in this study have 5 children, $23 \%$ have 4 
children, 18

$\%$ have 3 children, $20 \%$ have 2 children, and $16 \%$ have only 1 child. $57 \%$ of the children in this study were boys and $43 \%$ were girls. Moreover, $71 \%$ of mothers reported that their kids have no obesity and $29 \%$ reported having at least obese child. Demographic characteristics of the sample are shown in table 1.

Table 1: Demographic characteristics of the sample

\begin{tabular}{|c|c|c|c|}
\hline Item & $\begin{array}{l}\text { Percentage } \\
(\mathrm{N}=254)\end{array}$ & Item & $\begin{array}{l}\text { Percentage } \\
(\mathrm{N}=254)\end{array}$ \\
\hline $\begin{array}{l}\text { Age } \\
\qquad \begin{array}{l}20 \text { to } 30 \\
31 \text { to } 40 \\
41 \text { to } 50 \\
51 \text { and older }\end{array}\end{array}$ & $\begin{array}{l}20.6 \% \\
61.9 \% \\
11.5 \% \\
6 \%\end{array}$ & $\begin{array}{l}\text { Family income } \\
\text { Less than } 3,000 \mathrm{SR} \\
3,100 \text { to } 7,000 \mathrm{SR} \\
7,100 \text { to } 10,000 \mathrm{SR} \\
>10,000 \mathrm{SR}\end{array}$ & $\begin{array}{l}10.4 \% \\
27.2 \% \\
28 \% \\
34.4 \%\end{array}$ \\
\hline $\begin{array}{l}\text { Education } \\
\text { Read \& write } \\
\text { Middle school } \\
\text { High school } \\
\text { University graduate }\end{array}$ & $\begin{array}{l}16.8 \% \\
10.8 \% \\
24.8 \% \\
47.6 \% \\
\end{array}$ & $\begin{array}{l}\text { Family members } \\
1 \text { to } 4 \\
5 \text { to } 7 \\
8 \text { to } 10\end{array}$ & $\begin{array}{l}29 \% \\
41 \% \\
23 \%\end{array}$ \\
\hline $\begin{array}{l}\text { Marital Status } \\
\text { Married } \\
\text { Divorced } \\
\text { Widowed }\end{array}$ & $\begin{array}{l}90 \% \\
6.4 \% \\
3.6 \%\end{array}$ & $\begin{array}{l}\text { Number children } \\
1 \\
2 \\
3 \\
4 \\
5 \\
6 \text { and more }\end{array}$ & $\begin{array}{l}16 \% \\
20 \% \\
18 \% \\
23 \% \\
13 \% \\
10 \% \\
\end{array}$ \\
\hline $\begin{array}{l}\text { Occupation } \\
\text { Working } \\
\text { House wives }\end{array}$ & $\begin{array}{l}55.5 \% \\
44.5 \% \\
\end{array}$ & $\begin{array}{l}\text { Children gender } \\
\text { Boys } \\
\text { Girls } \\
\end{array}$ & $\begin{array}{l}57 \% \\
43 \% \\
\end{array}$ \\
\hline $\begin{array}{l}\text { Fixed family income } \\
\text { Fixed } \\
\text { Not fixed }\end{array}$ & $\begin{array}{l}88 \% \\
12 \%\end{array}$ & $\begin{array}{l}\text { Obese child } \\
\text { Yes } \\
\text { No }\end{array}$ & $\begin{array}{l}29 \% \\
71 \%\end{array}$ \\
\hline
\end{tabular}

Regarding lifestyle of children, data showed that $78 \%$ of children in this study did not practice any kind of sport, while half of the $22 \%$ who were practicing sport were practicing football, and $13 \%$ were practicing running, and $15.5 \%$ were practicing swimming. $60 \%$ of the children in this study practice sport for less than an hour per day, $27 \%$ practice sport from 1 to 2 hours per day, 13\% practice sport for 3 to 4 hours per day. $57 \%$ receive 3 basic meals a day, $29.5 \%$ receive less than 3 meals a day and $13.5 \%$ receive more than 3 meals a day. $73 \%$ eat their breakfast daily, and $27 \%$ don't eat breakfast regularly. $60 \%$ eat fast food sometimes, $14 \%$ eat fast food most of the time, and $26 \%$ don't eat fast food. $52 \%$ of the sample reported that carbohydrates are the proffered food of their kids. $76 \%$ of mothers reported that they organize their kid's meal time, while $24 \%$ reported that their kids eat a lot during night time. $56 \%$ of the mothers indicated that their kids watch TV from 1 to 3 hours per day, 32\% watches TV from 4 to 6 hours a day, and $11 \%$ watch TV for more than 6 hours a day. In addition, $49 \%$ of the mothers stated that their kids use the internet and play video games from 1 to 3 hours daily, 33.5\% use internet and play video games from 4 to 6 hours daily and 9\% use internet and play video games for more than 6 hours a day. Smoking was reported only in $1.7 \%$ of children in the sample; on the other hand, $52 \%$ reported that their kids stay up till late. Obesity related diseases was reported among $5 \%$ of the children in this study, and $20.5 \%$ of the mothers indicated that they don't know if their kids have obesity related disease or not, while $70.5 \%$ reported that their kids has no obesity related diseases. Among those who have obesity related disease, DM was the most common. $70 \%$ don't do medical checkup regularly for their kids, while $30 \%$ do medical checkup regularly. Sixty three per cent conveyed that they don't check their kid's weight regularly and 37\% used to check their kids weight. $73 \%$ indicated that they did not try any dieting regimen for their kids and $27 \%$ tried dieting programs. Out of those who tried diet regimen; $20 \%$ do not adhere, while $12 \%$ reported that they adhere to diet programs, and $44 \%$ adhere to some degree. Twenty four per cent reported that dieting trials did not help reducing their kid's weight while $17 \%$ reported that the dieting trials help reducing their kid's weight and $40 \%$ were not sure if their kid's weight was reduced or not. Children's life style in this study is reported in table 2. 
Table 2: Children's lifestyle as reported by mothers

\begin{tabular}{|c|c|c|c|}
\hline Item & Responses & Item & Responses \\
\hline $\begin{array}{l}\text { Practice sports } \\
\text { Yes } \\
\text { No }\end{array}$ & $\begin{array}{l}22 \% \\
78 \%\end{array}$ & $\begin{array}{l}\text { Use internet/play video games } \\
1 \text { to } 3 \text { hours/day } \\
4 \text { to } 6 \text { hours/day } \\
\text { More than } 6 \text { hours/ day }\end{array}$ & $\begin{array}{l}49 \% \\
33.5 \% \\
9 \%\end{array}$ \\
\hline $\begin{array}{c}\text { Type of sports } \\
\text { Football } \\
\text { Running } \\
\text { Swimming } \\
\text { Others }\end{array}$ & $\begin{array}{l}50 \% \\
13 \% \\
15.5 \% \\
21.5 \%\end{array}$ & $\begin{array}{c}\text { Smoke } \\
\text { Yes } \\
\text { No }\end{array}$ & $\begin{array}{l}1.7 \% \\
98.3 \%\end{array}$ \\
\hline $\begin{array}{l}\text { Time of practicing sports } \\
\text { Less than } 1 \text { hour } \\
1 \text { to } 2 \text { hours } \\
3 \text { to } 4 \text { hours }\end{array}$ & $\begin{array}{l}60 \% \\
27 \% \\
13 \% \\
\end{array}$ & $\begin{array}{l}\text { Stay up tell late } \\
\text { Yes } \\
\text { No }\end{array}$ & $\begin{array}{l}52 \% \\
48 \%\end{array}$ \\
\hline $\begin{array}{l}\text { How many meals a day } \\
\text { Less than } 3 \\
3 \text { meals } \\
\text { More than } 3\end{array}$ & $\begin{array}{l}29.5 \% \\
57 \% \% \\
13.5 \% \\
\end{array}$ & $\begin{array}{l}\text { Obesity related diseases } \\
\text { Yes } \\
\text { No } \\
\text { Not sure }\end{array}$ & $\begin{array}{l}5 \% \\
70.5 \% \\
20.5 \% \\
\end{array}$ \\
\hline $\begin{array}{l}\text { Breakfast } \\
\text { Yes } \\
\text { No }\end{array}$ & $\begin{array}{l}73 \% \\
27 \%\end{array}$ & $\begin{array}{l}\text { Check up } \\
\text { Yes } \\
\text { No }\end{array}$ & $\begin{array}{l}30 \% \\
70 \%\end{array}$ \\
\hline $\begin{array}{l}\text { Fast food } \\
\text { Most of the time } \\
\text { Sometimes } \\
\text { No }\end{array}$ & $\begin{array}{l}14 \% \\
60 \% \\
26 \% \\
\end{array}$ & $\begin{array}{c}\text { Weight } \\
\text { Yes } \\
\text { N0 }\end{array}$ & $\begin{array}{l}37 \% \\
63 \%\end{array}$ \\
\hline $\begin{array}{l}\text { Proffered food elements } \\
\text { Carbs } \\
\text { Vegetables } \\
\text { Protein } \\
\text { Fruits } \\
\text { Mix }\end{array}$ & $\begin{array}{l}52 \% \\
9.6 \% \\
20.2 \% \\
9.8 \% \\
8.4 \% \\
\end{array}$ & $\begin{array}{l}\text { Diet regimen } \\
\text { Yes } \\
\text { No }\end{array}$ & $\begin{array}{l}27 \% \\
73 \%\end{array}$ \\
\hline $\begin{array}{l}\text { Meal time } \\
\text { Organized } \\
\text { Night time }\end{array}$ & $\begin{array}{l}76 \% \\
24 \%\end{array}$ & $\begin{array}{l}\text { Adhere to diet regimen } \\
\text { Yes } \\
\text { No } \\
\text { To some degree }\end{array}$ & $\begin{array}{l}12 \% \\
20 \% \\
44 \% \\
\end{array}$ \\
\hline $\begin{array}{l}\text { Watching TV } \\
1 \text { to } 3 \text { hours/day } \\
4 \text { to } 6 \text { hours/day } \\
\text { More than } 6 \text { hours/ day }\end{array}$ & $\begin{array}{l}56 \% \\
32 \% \\
11 \% \\
\end{array}$ & $\begin{array}{l}\text { Regimen help reduce weight } \\
\text { Yes } \\
\text { No } \\
\text { Not sure }\end{array}$ & $\begin{array}{l}17 \% \\
24 \% \\
40 \% \\
\end{array}$ \\
\hline
\end{tabular}

As regard mother's knowledge about causes of obesity among children, mothers in this study conveyed a relatively good level of knowledge regarding causes of obesity among children with a mean score of 18.24(3.4). Seventy nine per cent of the mothers know and $21 \%$ don't know that genes could be a cause of obesity among children. $88.4 \%$ know and $11.6 \%$ don't know that unbalanced diet could be a cause of obesity among children. 91.5\% know and $8.5 \%$ don't know that eating much food could be a cause of obesity. $84.7 \%$ know and $15.3 \%$ don't know that lifestyle is a possible cause of obesity among children. $65.7 \%$ know and $34.3 \%$ don't know that psychological problems might cause obesity, while $72 \%$ know and $28 \%$ don't know that physical inactivity is a possible cause of obesity among children. $83.7 \%$ know and $36.3 \%$ don't know that family problems might be a reason for obesity. $85 \%$ know and $15 \%$ don't know that eating unhealthy diet could be a cause of obesity among children. $63 \%$ know and $37 \%$ don't know that low self-esteem could cause obesity in children. $71 \%$ know and $29 \%$ don't know that anxiety and depression are potential causes of obesity. On the other hand, $52 \%$ know and $47 \%$ don't know that violence and crisis could be probable reasons of obesity. $73 \%$ know and $27 \%$ don't know that receiving medication might initiate obesity among children. Further, $85.5 \%$ know and 14.5\% do not know that eating much food at night might precipitate obesity. Finally, $89.6 \%$ know and $10,4 \%$ don't know that mothers role could affect children weight. Mothers' knowledge regarding causes of obesity in children is presented in table 3 . 
Table 3: Mothers knowledge regarding causes of obesity among children

\begin{tabular}{|l|l|l|}
\hline Item & Know & Don't know \\
\hline Genes & $79 \%$ & $21 \%$ \\
\hline Unbalanced diet & $88.4 \%$ & $11.6 \%$ \\
\hline Eating much food & $91.5 \%$ & $8.5 \%$ \\
\hline Lifestyle & $84.7 \%$ & $15.3 \%$ \\
\hline Psychological problems & $65.7 \%$ & $34.3 \%$ \\
\hline Physical inactivity & $72 \%$ & $28 \%$ \\
\hline Family problems & $83.7 \%$ & $36.3 \%$ \\
\hline Unhealthy diet & $85 \%$ & $15 \%$ \\
\hline Low self-esteem & $63 \%$ & $37 \%$ \\
\hline Anxiety and depression & $71 \%$ & $29 \%$ \\
\hline Violence and crisis & $52 \%$ & $47 \%$ \\
\hline Receiving medications & $73 \%$ & $27 \%$ \\
\hline Eating much food at night & $85.5 \%$ & $14.5 \%$ \\
\hline Mothers role & $89.6 \%$ & $10.4 \%$ \\
\hline
\end{tabular}

Some demographic variables such as age, education, work, and income were correlated to total mother's knowledge of causes of obesity among children. Pearson product moment correlation indicated that there were a significant mild to moderate correlation between knowledge and education $(\mathrm{r}=.31)$, income $(\mathrm{r}=.28)$, work $(\mathrm{r}=$. 23 ) respectively. Having an obese child showed low and insignificant correlation with mothers' knowledge $(r=$ .15). Mothers who were well educated, working and who have high income had better knowledge about causes of obesity among their children. Correlation among selected study variables is shown in table 4.

Table 4: correlation among selected study variables

\begin{tabular}{|c|c|c|c|c|c|}
\hline & Age & Education & Work & Income & Obese child \\
\hline $\begin{array}{c}\text { Knowledge } \\
\mathrm{r}=\end{array}$ & $.10 *$ & $.31 *$ & $.23^{*}$ & $.28 *$ & $.14 *$ \\
\hline $\mathrm{p}$ value & .13 & .000 & .000 & .000 & .034 \\
\hline
\end{tabular}

\section{Discussion}

Childhood obesity has been increasing over the past few decades and has become a public health concern in both developed and developing countries (Karmik S \& Kanekar A 2012) Childhood obesity has more than doubled in children and quadrupled in adolescents in the past 30 years. The percentage of children aged 6-11 years in the United States who were obese increased from $7 \%$ in 1980 to nearly $18 \%$ in 2012. Similarly, the percentage of adolescents aged $12-19$ years who were obese increased from 5\% to nearly $21 \%$ over the same period. In 2012 , more than one third of children and adolescents were overweight or obese (Ogden et al 2014)

In the current study a descriptive cross-sectional design was utilized to assess the knowledge of Saudi mothers regarding causes of obesity among children. A convenient sample of 254 mothers were recruited for the study. Data was collected using a semi structured interview questionnaire. Data was collected from several sittings such as shopping malls and work places during subjects break.

In the USA, based on the NHANES (National Health and Nutrition Examination Survey) report, there is an increase in overall prevalence of obesity by more than $300 \%$ since in 1976 and over $70 \%$ since NHANES III in 1994 among children aged 219- years old (The second National Health and Nutrition Examination Survey. 2014)

In the current study high percentage of the mothers in the sample had good knowledge about cases of obesity. Nanty one percent were aware that eating much food is the leading case of children obesity, More than four fifth of the mother were aware that lifestyles is another factor of children's obesity. About only half (52\%) were aware that violence and crisis could be a cause of children's obesity. A good mother's knowledge causes of obesity among children is essential for the implementation of an effective prevention policy.

Obesity and overweight constitute an important health problem affecting a proportion of Saudi population. A study was conducted in Jeddah, where the researchers analyzed data between 1994- 2000 for school children and adolescents aged 10- 20, a significant increase was found in the average BMI for both sexes between 1994 and 2000 on the 50th percentile but even higher on the 85 th and 95 th percentile, the increase in body weight and BMI were marked for all age groups; however boys showed the largest increase at an age of 1016- years and girls showed the lowest at age 14- 16 years (Abalkhail 2002)

In a thesis study by Mohamed Altrashidi to assess the prevalence, risk factors and perception of overweight and obesity in kuwaiti children, he was found that one quarter of the surveyed children $(25.5 \%)$ were overweight. 
An additional one third of the participants (36.5\%) were classified as obese. The nurses' measurements of BMI disagreed with the children's perceptions of their own weight and obesity. The children's perceptions were better aligned with their parents' perceptions of overweight and obesity. Multiple regression models found that the BMI of male children increased significantly with age, if they had overweight siblings, spent time on sedentary activities, or regularly ate food from fast food restaurants. The BMI of female children also increased significantly with age, if they had overweight siblings, ate at fast food restaurants, and for who not walk to and from school (Mohamed Altrashidi 2016)

In this study there were a highly statistically significant relationship between mothers knowledge and their education, job, income and whether they have obese child $(p=0.00, p=0.000, p=0.000$ and $p=0.034$ respectively. This indicates that mother's knowledge increases with the increase of education level, income and if they have obese child. However the mother's knowledge did not has any statistically relationship with their age.

Children's obesity has been identified as a growing global problem. The risk of children's obesity as it is linked to the increased risk of type 2 diabetes, hyperlipidemia, hypertension, and adult obesity.6Given the risk of development of severe health consequences and the heavy burden on the health care system, effective prevention targeting children and their parents is the key to combating this health problem (CDC 2011)

One limitation of our study was that the study did not assess the impact of mother's knowledge on their children's weight. This study highlights the need for future research to explore effective strategies for helping busy physicians increase parents' awareness of their children's overweight and obese status and promote a healthy body weight for all children. Increasing parents' awareness of their children's weight problems is the first step in preventing pediatric obesity

\section{Conclusion}

Obesity means having too much body fat. It is different from being overweight, which means weighing too much. Both terms mean that a person's weight is greater than what's considered healthy for his or her height. Children grow at different rates, so it isn't always easy to know when a child is obese or overweight. Ask your health care provider to check whether your child's weight and height are in a healthy range. If a weight-loss program is necessary, involve the whole family in healthy habits so your child doesn't feel singled out. Encourage healthy eating.

\section{Recommendation}

Serving more fruits and vegetables, Buying fewer soft drinks and high-fat, high-calorie snack foods, Making sure your child eats breakfast every day, Eating fast food less often, Not using food as a reward, Physical activity is also very important. Kids need about 60 minutes each day. It does not have to happen all at once. Several short periods of activity during the day are just as good.

\section{References}

Abalkhail B. Overweight and obesity among Saudi Arabian Children and adolescents between 1994 and 2000. East Mediter Health J 2002; 8 (4- 5):470-9. [PubMed]

CDC. National diabetes fact sheet: national estimates and general information on diabetes and prediabetes in the United States, 2011. Atlanta, GA: U.S. Department of Health and Human Services

Gallois P, Vallée JP, Lenoc Y. Adulthood obesity: complex and difficult approach of a real epidemic approach [in French]. Médecine. 2008;4:67-71. doi:10.1684/med.2008.0235

Mohamed Altrashidi 2016. The Prevalence, Risk Factors and Perception of Overweight and Obesity in Kuwaiti Children: A Mixed Methods Approach https://researchbank.rmit.edu.au/eserv/rmit:161666/Alrashidi.pdf

Ogden CL, Carroll MD, Kit BK, Flegal KM. Prevalence of childhood and adult obesity in the United States, 20112012.Journal of the American Medical Association 2014; 311(8):806-14. doi: 10.1001/jama.2014.732. [PMC free article] [PubMed]

The second National Health and Nutrition Examination Survey, NHANES II Available at: http://www.cdc.gov/nchs/nhanes/nhanesii.htm Accessed May12, 2014

Young-Hyman, D., Herman, L. J., Scott, D. L., Schlundt, D. G. (2000) Care giver perception of children's obesityrelated health risks: a study of African American families. Obes Res 8: 241-248 